\title{
The effect of the growth rate and meatiness of young gilts during rearing on the growth and development of their reproductive system
}

\author{
Wojciech Kapelański, Hanna Jankowiak, Maria Bocian, Salomea Grajewska, Jan Dybała, \\ Aleksandra Cebulska \\ University of Technology and Life Sciences in Bydgoszcz, Department of Pig Breeding, Bydgoszcz, Poland
}

Received March 7, 2012

Accepted October 23, 2012

\begin{abstract}
The effects of reproduction performance of sows may be subject to the degree of progress growth and development of their reproductive system. The aim of the study focused on the effect of the growth rate and meatiness on the potential fertility of gilts. In total, developmental stages of reproductive organs of gilts of two breeds Polish Large White $(\mathrm{n}=100)$ and Polish Landrace $(\mathrm{n}=100)$ were used. The animals were divided into three groups depending on their daily gains $(\leq 850 \mathrm{~g}, 851-1000 \mathrm{~g}$ and $>1000 \mathrm{~g})$. Feed efficiency was similar in each group, and amounted to $2.91,2.57$ and $2.34 \mathrm{~kg} / \mathrm{kg}$, respectively. Meat content in carcass demonstrated significant differences $(P \leq 0.01)$ between three groups for the Polish Landrace breed $(61 \%, 61 \%$ and $59.2 \%$, respectively). An adverse effect of a high growth rate was confirmed for uterine weight $(P \leq 0.05)$, vaginal and cervical length $(P \leq 0.01)$, total length of the uterine horns $(P \leq 0.01)$ and uterine capacity $(P \leq 0.01)$ mainly in the Polish Large White breed. Similarly to ovarian volume, ovarian weight showed significant differences $(P \leq 0.01 ; P \leq 0.05)$, however disproportionately to the rate of growth. The most favourable properties have been demonstrated in the Polish Large White characterized by moderate growth rate $(P \leq 0.01)$. Research on the scope of the assessment growth and development of the reproductive system of prepubertal gilts is very limited. Thus, this study brings important data about factors affecting morphometrical characteristics of the uteri, ovaries and oviducts of gilts.
\end{abstract}

Female pig, growth rate, carcass musculature, uterus measure, ovary volume

The number of piglets born and weaned from sow during the year is currently one of the most important characteristics affecting the effective production of pigs. Some researchers are of the opinion that the established genetic improvement in terms of musculature of the pigs kept today worsens the reproductive performance features in sows (Eliasson et al. 1991; Rydhmer et al. 1994). Pig reproduction is influenced by nutrition (Tydlitát et al. 2008), especially if the process of protein deposition in the body is accompanied by a low feed intake and high feed efficiency (Kerr and Cameron 1995).

One of the most significant factors restricting fertility of gilts and sows may be the state of growth and development of their reproductive system (Rillo et al. 2001; Dybała et al. 2004; Szostak 2010). The morphometrical evaluation of the reproductive system of gilts before reaching sexual maturity could be a useful indicator for the estimation of early potential and actual fertility of sows. The test factors influencing growth and development of the reproductive system becomes of more practical importance in this context.

The aim of this study was to assess the impact of the growth rate of the gilt's body weight, feed efficiency and carcass meatiness on the state of development of the reproductive system in Polish Large White and Polish Landrace breeds.

\section{Materials and Methods}

The study was conducted at the Pig Testing Station in Mełno, Poland in the years 2009-2010 on 100 female gilts of Polish Large White (PLW) and 100 gilts of Polish Landrace (PL) breed. The selection of experimental gilts and the conditions of their nutrition and maintenance were consistent with the methodology developed for the Pig

Address for correspondence:

Hanna Jankowiak, PhD.

Department of Pig Breeding

University of Technology and Life Sciences in Bydgoszcz

Kordeckiego 20, 85-225 Bydgoszcz, Poland

Phone: +48523749748
Fax: +48523228158
E-mail: jankowiak@utp.edu.pl
http://actavet.vfu.cz/ 
Testing Station (Różycki and Tyra 2010). Routine examination covered growth rate of female pigs from a body weight of 30-100 kg. The animals were kept in the individual pens with straw. Gilts were fed ad libitum of feed mixture containing $13.00 \mathrm{MJ} / \mathrm{kg}$ metabolizable energy and $12.8 \%$ of crude protein. The animals were slaughtered at a body weight of approximately $100 \mathrm{~kg}$. The fattening assessment of gilts included: age at slaughter, body weight, average daily gains, feed consumption per $1 \mathrm{~kg}$ gain and the meatiness. The gilts were divided into three groups $A(n=46), B(n=97)$ and $C(n=57)$ according to average daily gains $\leq 850 \mathrm{~g}, 851-1000 \mathrm{~g}$ and $>1000 \mathrm{~g}$, respectively.

Complete reproductive systems of gilts collected directly after slaughter served as material for morphometric evaluation. After dissection of the reproductive systems, vaginal length was measured and the uterus was separated including the cervix, oviduct and ovaries. The weight of the uterus with the broad ligament was then determined and after separation the uterine weight was measured without the ligament. Measurements of cervical length, length of the uterine horns (right and left) and length of the oviducts (left and right) were taken. In order to obtain a more comprehensive description of the size of uterus in the analyzed gilts the ratio between the weight and length of the uterus $(\mathrm{g} / \mathrm{cm})$ was calculated. Analysis of the uterine capacity was based on the method applied to determine the capacity of cavernous organs developed by Brudnicki et al. (2001) and modified for the purpose of uterine capacity measurement at the Department of Pig Breeding of the University of Technology and Life Sciences in Bydgoszcz. Detailed description of the procedure is presented in our previous study (Kapelański et al. 2012). Ovaries were subject to detailed analysis involving determination of their weight and volume by immersing the ovaries in a calibrated measuring cylinder containing a predetermined volume of saline.

Both the arithmetic mean (x) and standard deviation (s) were calculated. A two-way analysis of variance ANOVA/MANOVA was performed allowing for the breed and growth rate of the gilts. The significance of differences between the analysed groups was estimated using the Duncan test. The STATISTICA 8 PL (2008) computer software was used for calculations.

\section{Results}

Table 1 shows the fattening and slaughter traits of PLW and PL gilts depending on their daily gains within a test period from the weight of $30 \mathrm{~kg}$ to $100 \mathrm{~kg}$. Gilts coming

Table 1. Fattening and slaughter performance characteristics in Polish Large White and Polish Landrace gilts depending on the growth rate.

\begin{tabular}{|c|c|c|c|c|c|}
\hline \multirow{2}{*}{ Characteristic } & \multirow{2}{*}{ Breed } & \multicolumn{3}{|c|}{ Daily gains (g) } & \multirow{2}{*}{ Breed average } \\
\hline & & $\mathrm{A} \leq 850$ & B $851-1000$ & $C>1000$ & \\
\hline \multirow[t]{2}{*}{ Number } & PLW & 23 & 49 & 28 & 100 \\
\hline & PL & 23 & 48 & 29 & 100 \\
\hline Total & & 46 & 97 & 57 & 200 \\
\hline \multirow[t]{2}{*}{ Age at slaughter (days) } & PLW & $189.43^{\mathrm{Ax}} \pm 14.44$ & $167.73^{\mathrm{B}} \pm 15.07$ & $162.18^{\mathrm{Bx}} \pm 15.16$ & $171.17^{\mathrm{x}} \pm 18.04$ \\
\hline & PL & $179.39^{\mathrm{Ay}} \pm 17.04$ & $166.92^{\mathrm{B}} \pm 15.75$ & $154.10^{\mathrm{Cy}} \pm 14.75$ & $166.07^{\mathrm{y}} \pm 18.09$ \\
\hline Average & & $184.41^{\mathrm{A}} \pm 16.42$ & $167.33^{\mathrm{B}} \pm 15.34$ & $158.07^{\mathrm{C}} \pm 15.37$ & - \\
\hline \multirow[t]{2}{*}{ Daily gains (g/day) } & PLW & $756^{\mathrm{A}} \pm 60$ & $931^{\mathrm{Bx}} \pm 44$ & $1047^{\mathrm{BX}} \pm 38$ & $923 \pm 114$ \\
\hline & PL & $757^{\mathrm{A}} \pm 74$ & $942^{\text {Bay }} \pm 42$ & $1098^{\mathrm{CbY}} \pm 66$ & $945 \pm 135$ \\
\hline Average & & $757^{\mathrm{A}} \pm 67$ & $937^{\mathrm{B}} \pm 43$ & $1073^{C} \pm 125$ & - \\
\hline \multirow[t]{2}{*}{ Feed efficiency $(\mathrm{kg} / \mathrm{kg})$} & PLW & $2.90^{\mathrm{A}} \pm 0.33$ & $2.64^{\mathrm{Bx}} \pm 0.35$ & $2.39^{\mathrm{B}} \pm 0.35$ & $2.63 \pm 0.39$ \\
\hline & PL & $2.92^{\mathrm{A}} \pm 0.25$ & $2.49^{\mathrm{Bay}} \pm 0.32$ & $2.30^{\mathrm{Bb}} \pm 0.27$ & $2.53 \pm 0.37$ \\
\hline Average & & $2.91^{\mathrm{A}} \pm 0.29$ & $2.57^{\mathrm{B}} \pm 0.34$ & $2.34^{\mathrm{C}} \pm 0.31$ & - \\
\hline \multicolumn{6}{|l|}{ Average back fat } \\
\hline \multirow[t]{2}{*}{ thickness (mm) } & PLW & $13.56 \pm 0.27$ & $14.42 \pm 0.38$ & $14.12 \pm 0.31$ & $14.10 \pm 0.34$ \\
\hline & PL & $13.20 \pm 0.35$ & $13.40 \pm 0.29$ & $14.41 \pm 0.20$ & $13.60 \pm 0.28$ \\
\hline Average & & $13.38 \pm 0.31$ & $13.92 \pm 0.34$ & $14.27 \pm 0.26$ & - \\
\hline \multirow[t]{2}{*}{ Meat in carcass $(\%)$} & PLW & $59.79 \pm 3.36$ & $60.02 \pm 3.40$ & $59.35 \pm 3.04$ & $59.78 \pm 3.28$ \\
\hline & PL & $61.07^{\mathrm{A}} \pm 2.49$ & $60.69^{\mathrm{a}} \pm 3.14$ & $59.02^{\mathrm{Bb}} \pm 2.49$ & $60.29 \pm 2.91$ \\
\hline Average & & $60.43^{\mathrm{a}} \pm 2.99$ & $60.35^{\mathrm{a}} \pm 3.28$ & $59.18^{b} \pm 2.75$ & - \\
\hline
\end{tabular}

PLW - Polish Large White, PL - Polish Landrace. Significance in rows: ${ }^{\mathrm{A}, \mathrm{B}, \mathrm{C}} P \leq 0.01$, ${ }^{\mathrm{a}, \mathrm{b}} P \leq 0.05$, in columns: ${ }^{\mathrm{X}}, \mathrm{Y} P \leq 0.01,{ }^{\mathrm{x}} \mathrm{y} P \leq 0.05$. 
from the group with the lowest gains compared to other groups $(P \leq 0.01)$ were also the oldest (184.41 days) at slaughter. There were no differences $(P \leq 0.05)$ between the two breeds of gilts in terms of daily gains, even though the PL gilts were slightly younger at slaughter than the PLW gilts. Feed efficiency was very high in gilts from the groups showing daily gains above $1000 \mathrm{~g} /$ day and did not exceed $2.4 \mathrm{~kg} / \mathrm{kg}$ compared to other groups $(P \leq 0.01)$. Estimated carcass musculature was very high and showed significant variation depending on the rate of growth only in the PL gilts $(P \leq 0.01)$. Considerably lower meatiness characterized the animals with the largest daily gains compared to the slowest growing gilts.

Table 2. Uterine weight and dimensions of Polish Large White and Polish Landrace gilts depending on the growth rate.

\begin{tabular}{|c|c|c|c|c|c|}
\hline \multirow{2}{*}{ Characteristic } & \multirow{2}{*}{ Breed } & \multicolumn{3}{|c|}{ Daily gains $(\mathrm{g})$} & \multirow{2}{*}{ Breed average } \\
\hline & & $\mathrm{A} \leq 850$ & B $851-1000$ & $\mathrm{C}>1000$ & \\
\hline \multicolumn{6}{|l|}{ Uterine weight with } \\
\hline \multirow[t]{2}{*}{ ligament (g) } & PLW & $168.37^{\mathrm{a}} \pm 74.85$ & $145.59 \pm 56.29$ & $133.57^{b x} \pm 39.70$ & $147.46 \pm 58.04$ \\
\hline & PL & $168.30 \pm 72.79$ & $163.48 \pm 72.67$ & $165.05^{y} \pm 67.10$ & $165.05 \pm 70.44$ \\
\hline Average & & $168.34 \pm 73.00$ & $154.44 \pm 65.20$ & $149.59 \pm 57.13$ & - \\
\hline \multicolumn{6}{|l|}{ Uterine weight without } \\
\hline \multirow[t]{2}{*}{ ligament $(\mathrm{g})$} & PLW & $144.45 \pm 64.98$ & $127.46 \pm 53.18$ & $119.69 \pm 38.08$ & $129.19^{\mathrm{x}} \pm 52.77$ \\
\hline & PL & $150.78 \pm 69.49$ & $145.43 \pm 68.12$ & $146.14 \pm 62.19$ & $146.87^{y} \pm 66.14$ \\
\hline Average & & $147.62 \pm 66.60$ & $136.35 \pm 61.38$ & $133.15 \pm 53.00$ & - \\
\hline \multirow[t]{2}{*}{ Vaginal length $(\mathrm{cm})$} & PLW & $11.67^{\mathrm{a}} \pm 2.38$ & $10.11 \pm 1.36$ & $8.87^{\mathrm{b}} \pm 2.47$ & $10.53 \pm 2.41$ \\
\hline & PL & $9.89^{\mathrm{a}} \pm 2.03$ & $10.25^{\mathrm{a}} \pm 3.01$ & $6.67^{b} \pm 0.58$ & $9.55 \pm 2.58$ \\
\hline Average & & $11.00^{\mathrm{A}} \pm 2.38$ & $10.18^{\mathrm{a}} \pm 2.21$ & $8.27^{\mathrm{Bb}} \pm 2.33$ & - \\
\hline \multirow[t]{2}{*}{ Cervical length $(\mathrm{cm})$} & PLW & $13.56^{\mathrm{a}} \pm 2.08$ & $12.47 \pm 2.24$ & $12.03^{b} \pm 2.18$ & $12.60 \pm 2.24$ \\
\hline & PL & $12.91 \pm 2.06$ & $12.45 \pm 2.63$ & $11.75 \pm 1.96$ & $12.35 \pm 2.35$ \\
\hline Average & & $13.24^{\mathrm{A}} \pm 2.08$ & $12.46 \pm 2.43$ & $11.89^{\mathrm{B}} \pm 2.06$ & - \\
\hline \multicolumn{6}{|l|}{ Length of uterine horns } \\
\hline \multirow[t]{2}{*}{$(\mathrm{R}+\mathrm{L})(\mathrm{cm})$} & PLW & $104.05^{\mathrm{a}} \pm 23.06$ & $97.20 \pm 14.70$ & $93.45^{\mathrm{b}} \pm 14.95$ & $97.72 \pm 17.28$ \\
\hline & PL & $106.89^{\mathrm{a}} \pm 18.50$ & $97.53 \pm 17.62$ & $96.51^{b} \pm 20.95$ & $99.38 \pm 19.10$ \\
\hline Average & & $105.47^{\mathrm{Aa}} \pm 20.72$ & $97.36^{b} \pm 16.13$ & $95.00^{\mathrm{B}} \pm 18.16$ & - \\
\hline \multicolumn{6}{|l|}{ Weight/length of horns } \\
\hline \multirow[t]{2}{*}{$(\mathrm{g} / \mathrm{cm})$} & PLW & $1.36 \pm 0.43$ & $1.33 \pm 0.59$ & $1.28 \pm 0.37$ & $1.33 \pm 0.50$ \\
\hline & PL & $1.43 \pm 0.64$ & $1.48 \pm 0.60$ & $1.48 \pm 0.41$ & $1.47 \pm 0.56$ \\
\hline Average & & $1.40 \pm 0.54$ & $1.41 \pm 0.60$ & $1.38 \pm 0.40$ & - \\
\hline \multirow[t]{2}{*}{ Uterine capacity $(\mathrm{cm} 3)$} & PLW & $140.30 \pm 88.39$ & $129.62 \pm 55.17$ & $131.31 \pm 55.46$ & $132.55^{\mathrm{x}} \pm 63.79$ \\
\hline & PL & $164.00 \pm 63.23$ & $145.74 \pm 57.79$ & $166.62 \pm 83.12$ & $155.99^{\mathrm{Y}} \pm 67.28$ \\
\hline Average & & $152.15 \pm 76.93$ & $137.60 \pm 56.77$ & $149.27 \pm 72.49$ & - \\
\hline
\end{tabular}

PLW - Polish Large White, PL - Polish Landrace. Significance in rows: ${ }^{\mathrm{A}, \mathrm{B}, \mathrm{C} P} \leq 0.01$, a, $P \leq 0.05$, in columns: ${ }^{\mathrm{X}, \mathrm{Y}} P \leq 0.01$, ${ }^{\mathrm{x}, \mathrm{y}} P \leq 0.05$.

Table 2 shows the impact of growth rate on the morphometric characteristics of the reproductive system of gilts. Uterine weight without the ligament in PLW gilts was significantly $(P \leq 0.05)$ lower than in PL gilts, regardless of the growth rate. Taking into account the weight of the uterus with the broad ligament, the differences between the breeds were significant $(P \leq 0.05)$ only in case of the gilts with the biggest daily gains and between the gilts with the largest and smallest gains within the PLW breed. The PLW gilts from group A had the heaviest uteruses compared to group $\mathrm{C}(P \leq 0.05)$. Cervical length 
showed no significant variability between the breeds and thus a highly significant negative impact of the growth rate on this section of the reproductive organ was demonstrated with regard to the mean value for both breeds. The slowest growing gilts exhibited the greatest cervical length $(P \leq 0.01)$. The total length of the uterine horns was the highest in gilts with the smallest daily gains below $850 \mathrm{~g}$ /day $(P \leq 0.01, P \leq 0.05)$. The PLW gilts were characterized by a lower capacity of the uterus compared to PL gilts $(P \leq 0.01)$. The vaginal length analyzed in the course of this experiment in gilts of both breeds was significantly $(P \leq 0.05)$ shorter in the fastest growing gilts than in the slow growing ones.

Table 3 shows the characteristics of the oviducts and ovaries. Both in the slow growing gilts of group A and the fast growing group $\mathrm{C}$ the length of the oviduct was very similar and even. The length of the right oviduct, however, was significantly shorter in PLW gilts

Table 3. Characteristics of the oviducts and ovaries of Polish Large White and Polish Landrace gilts depending on the growth rate.

\begin{tabular}{|c|c|c|c|c|c|}
\hline \multirow{2}{*}{ Characteristic } & \multirow{2}{*}{ Breed } & \multicolumn{3}{|c|}{ Daily gains (g) } & \multirow{2}{*}{ Breed average } \\
\hline & & $\mathrm{A} \leq 850$ & B 851-1000 & $\mathrm{C}>1000$ & \\
\hline \multicolumn{6}{|l|}{ Length of the right } \\
\hline \multirow[t]{2}{*}{ oviduct $(\mathrm{cm})$} & PLW & $18.88 \pm 2.74$ & $18.84 \pm 2.83$ & $18.93 \pm 3.75$ & $18.87^{\mathrm{x}} \pm 3.07$ \\
\hline & PL & $19.96 \pm 3.44$ & $20.39 \pm 4.80$ & $20.00 \pm 3.54$ & $20.18^{Y} \pm 4.14$ \\
\hline Average & & $19.42 \pm 3.12$ & $19.61 \pm 3.99$ & $19.47 \pm 3.66$ & - \\
\hline \multicolumn{6}{|l|}{ Length of the left } \\
\hline \multirow[t]{2}{*}{ oviduct $(\mathrm{cm})$} & PLW & $20.06 \pm 2.28$ & $20.12 \pm 2.85$ & $20.71 \pm 3.54$ & $20.27 \pm 2.93$ \\
\hline & PL & $20.79 \pm 3.38$ & $20.73 \pm 4.33$ & $21.13 \pm 3.21$ & $20.86 \pm 3.79$ \\
\hline Average & & $20.42 \pm 2.88$ & $20.42 \pm 3.65$ & $20.93 \pm 3.35$ & - \\
\hline \multicolumn{6}{|l|}{ Weight of the right } \\
\hline \multirow[t]{2}{*}{ ovary (g) } & PLW & $2.91^{\mathrm{A}} \pm 0.76$ & $3.62^{\mathrm{B}} \pm 0.99$ & $3.35 \pm 0.84$ & $3.38 \pm 0.93$ \\
\hline & PL & $3.44 \pm 1.08$ & $3.36 \pm 0.98$ & $3.42 \pm 1.00$ & $3.40 \pm 1.00$ \\
\hline Average & & $3.17 \pm 0.96$ & $3.50 \pm 0.99$ & $3.39 \pm 0.92$ & - \\
\hline \multicolumn{6}{|l|}{ Weight of the left } \\
\hline \multirow[t]{2}{*}{ ovary (g) } & PLW & $3.34 \mathrm{~A}^{\mathrm{x}} \pm 0.70$ & $4.15^{\mathrm{B}} \pm 1.21$ & $3.76 \pm 0.89$ & $3.85 \pm 1.07$ \\
\hline & PL & $3.98^{\mathrm{y}} \pm 1.28$ & $3.71 \pm 1.05$ & $3.62 \pm 1.21$ & $3.75 \pm 1.15$ \\
\hline Average & & $3.66 \pm 1.07$ & $3.93 \pm 1.15$ & $3.69 \pm 1.05$ & - \\
\hline \multicolumn{6}{|l|}{ Weight of ovaries } \\
\hline \multirow[t]{2}{*}{$(\mathrm{R}+\mathrm{L})(\mathrm{g})$} & PLW & $6.25 \mathrm{~A}^{\mathrm{x}} \pm 1.32$ & $7.77^{\mathrm{B}} \pm 2.10$ & $7.11 \pm 1.60$ & $7.24 \pm 1.90$ \\
\hline & PL & $7.42^{y} \pm 2.24$ & $7.08 \pm 1.77$ & $7.05 \pm 2.15$ & $7.15 \pm 1.98$ \\
\hline Average & & $6.83 \pm 1.91$ & $7.43 \pm 1.96$ & $7.08 \pm 1.88$ & - \\
\hline \multirow[t]{2}{*}{ Right ovary volume $\left(\mathrm{cm}^{3}\right)$} & PLW & $2.15^{\mathrm{a}} \pm 0.88$ & $2.77^{\mathrm{b}} \pm 1.07$ & $2.20^{\mathrm{a}} \pm 0.93$ & $2.47 \pm 1.03$ \\
\hline & PL & $2.53 \pm 0.91$ & $2.61 \pm 1.16$ & $2.32 \pm 0.93$ & $2.51 \pm 1.04$ \\
\hline Average & & $2.34 \pm 0.90$ & $2.70^{\mathrm{a}} \pm 1.11$ & $2.26^{\mathrm{b}} \pm 0.92$ & - \\
\hline \multirow[t]{2}{*}{ Left ovary volume $\left(\mathrm{cm}^{3}\right)$} & PLW & $2.50^{\mathrm{a}} \pm 0.96$ & $3.21^{\mathrm{Ab}} \pm 1.32$ & $2.30^{\mathrm{B}} \pm 0.91$ & $2.79 \pm 1.20$ \\
\hline & PL & $2.86 \pm 0.93$ & $2.84 \pm 1.33$ & $2.46 \pm 1.07$ & $2.73 \pm 1.18$ \\
\hline Average & & $2.68 \pm 0.95$ & $3.02^{\mathrm{A}} \pm 1.33$ & $2.38^{\mathrm{B}} \pm 0.98$ & - \\
\hline \multicolumn{6}{|l|}{ Ovarian volume } \\
\hline \multirow[t]{2}{*}{$(\mathrm{R}+\mathrm{L})(\mathrm{cm} 3)$} & PLW & $4.65^{\mathrm{a}} \pm 1.73$ & $5.98^{\mathrm{Ab}} \pm 2.29$ & $4.50^{\mathrm{B}} \pm 1.69$ & $5.26 \pm 2.12$ \\
\hline & PL & $5.38 \pm 1.71$ & $5.45 \pm 2.37$ & $4.78 \pm 1.93$ & $5.24 \pm 2.11$ \\
\hline Average & & $5.01 \pm 1.74$ & $5.72^{\mathrm{A}} \pm 2.33$ & $4.64^{\mathrm{B}} \pm 1.80$ & - \\
\hline
\end{tabular}

PLW- Polish Large White, PL - Polish Landrace. Significance in rows: ${ }^{\mathrm{A}, \mathrm{B}, \mathrm{C}} P \leq 0.01$, ${ }^{\mathrm{a}, \mathrm{b}} P \leq 0.05$, in columns: ${ }^{\mathrm{X}, \mathrm{Y}} P \leq 0.01$, x, $\mathrm{P} \leq 0.05$. 
than in PL gilts $(P \leq 0.01)$. Conversely, the length of the left oviducts was the same in gilts of both breeds. It seems that the differences in paired glands or reproductive organs are somewhat random and their differentiation is not subject to any fixed rules.

The weights of the right and left ovaries differed unsystematically between the compared groups of gilts, both in terms of the breed and growth rate. The weight sum of both ovaries (right + left) in PLW gilts with moderate rate of growth (group B) was significantly $(P \leq 0.01)$ higher than in the slow growing gilts of group A. Similarly, the volume of both ovaries combined showed significant differences in the size of the ovaries, disproportionately to the growth rate of gilts within the PLW breed only $(P \leq 0.01)$. Gilts characterized by a moderate growth rate demonstrated the largest ovarian volume. The average size of both ovaries calculated for animals of both breeds was also the smallest in the fastest growing gilts compared to those with a moderate growth rate $(P \leq 0.01)$.

\section{Discussion}

The rate of growth reflects the balance between synthesis and degradation of proteins in the body (Kristensen et al. 2002). The shift of cell metabolism towards increased deposition of proteins promotes higher body weight and carcass musculature growth. At the same time, faster growing animals demonstrate higher weight of internal organs in proportion to the increase in their body weight (Koong et al. 1982; Klindt et al. 1999).

Adequate developmental state of the vagina and cervix play a substantial role in the process of gilt fertilization and mating efficiency. Previous research on the effects of the vaginal and cervical length on the fertility of gilts involved measuring the depth of catheter penetration of these sections of the reproductive tracts during the first mating (Rillo et al. 2001; Tarocco and Kirkwood 2002; Dybała et al. 2004). It was shown that the total vaginal and cervical length in gilts may be a good predictor feature of the size of the litter. Larger litters were delivered by gilts with longer sections of these genital tracts (Dybała et al. 2004).

The length of the uterine horns limits the possibility of embryo implantation, determines proper development of foetuses and is a good predictor of litter size (Wu and Dziuk 1995; Vallet 2000). The results of research carried out by Eliass on et al. (1991) and by Kerr and Cameron (1995) indicated negative relationship between fertility and the increase in meatiness and feed efficiency. The results of our study also suggest a slower development of the uterus in gilts of both breeds demonstrating a very rapid growth but these gilts were younger. It cannot be unambiguously stated that the growth rate of gilts caused differences in the growth and development of their reproductive system. The age may have a greater importance, requiring further research. More intensive growth of the reproductive system of slowly growing gilts was found in research carried out by Szostak (2010).

Another feature characteristic of the potential fertility of gilts is the volumetrically determined capacity of the uterus. This trait, in our opinion, characterizes the possibility of providing ample space for the foetuses during pregnancy, ensures their adequate arrangement and proper development of the placentas (Bartol et al. 1993). Data obtained in the course of our study showed no relationship between the capacity of the uterus and the growth rate of gilts, it did, however, reveal a significant difference between the compared breeds.

The prepubertal period and the occurrence of regular cyclic changes in the ovarian function are preceded by dynamic metabolic and hormonal changes modulating the size of the ovarian follicles and the shape of the ovaries. Beltranena et al. (1993) identified two types of gilts distinguished by low and high episodic frequency of luteinizing hormone (LH) secretion pulses to the circulatory system, regardless of the growth rate of gilts. Gilts with a high frequency of LH pulses were characterized by a higher volume of fluid in the ovarian follicles, greater uterine weight and higher concentrations of estradiol $17 ß$ in plasma and follicular fluid compared to gilts with lower frequency of the LH output. In the opinion of these authors (Beltranena et al. 
1993), the variation in the course of sexual development is an innate characteristic independent of the intensity of feeding and fatness of gilts.

Certain differences observed in the course of this study in the size of ovaries occurred in PLW gilts only, positively distinguishing the group of gilts with a moderate growth rate demonstrated during the test period from the groups with the lowest and highest growth rates.

In conclusion it should be emphasized that the properties connected with the development of the reproductive system in prepubertal gilts showed a less favourable development of the reproductive system in gilts with very high growth rate and feed efficiency, particularly in PLW gilts. Faster growing gilts were also younger.

Further studies will clarify the extent to which the development of reproductive systems of gilts is affected by age and growth rate.

\section{Acknowledgements}

Supported by the State Committee for Scientific Research, Grant No. PB 0800/B/P01/2009/37.

\section{References}

Bartol FF, Wiley AA, Spencer TE, Vallet JL, Christensen RK 1993: Early uterine development in pigs. J Reprod Fertil Suppl 48: 99-116

Beltranena E, Aherne FX, Foxcroft GR 1993: Innate variability in sexual development irrespective of body fatness in gilts. J Anim Sci 71: 471-480

Brudnicki W, Skoczylas B, Jabłoński R 2001: Metrical features of some parts of the alimentary canal and liver in racoon dog (Nyctereutes procyonoides gray). EJPAU 4, Available online: http://www.ejpau.media.pl/volume4/ issue1/veterinary/art-01.html

Dybała J, Kapelański W, Kapelańska J, Wiśniewska J 2004: Gilt fertility in relation to vagina-cervix length. Ann Anim Sci Suppl 2: 17-20

Eliasson L, Rydhmer L, Einarsson S, Andersson K 1991: Relationships between puberty and production traits in the gilt. 1. Age at puberty. Anim Reprod Sci 25: 143-154

Kapelanski W, Jankowiak H, Bocian M, Grajewska S, Dybała J, Zmudzińska A 2012: Morphometric characteristics of reproductive systems in Polish Large White and Polish Landrace gilts a body weight at $100 \mathrm{~kg}$. Ann Anim Sci 13: 45-53

Kerr JC, Cameron ND 1995: Reproductive performance of pigs selected for components of efficient lean growth. Anim Sci 60: 281-290

Klindt J, Yen JT, Christenson RK 1999: Effect of prepubertal feeding regimen on reproductive development of gilts. J Anim Sci 77: 1968-1976

Koong LJ, Nienaber JA, Pekas JC, Yen JT 1982: Effects of plane of nutrition on organ size and fasting heat production in pigs. J Nutr 112: 1638-1642

Kristensen L, Therkildsen M, Riis B, Sorensen MT, Oksbjerg N, Purslow PP, Ertbjerg P 2002: Dietary-induced changes of muscle growth rate in pigs: Effects on in vivo and postmortem muscle proteolysis and meat quality. J Anim Sci 80: 2862-2871

Różycki M, Tyra M 2010: Method of evaluating of fattening and slaughter value of pigs in testing stations. In: Report on Pig Breeding in Poland. Issued by National Research Institute of Animal Production in Kraków. 93-117

Rillo MS, de Alba RC, Rodriguez AR, Cidoncha R, Ziecik AJ 2001: Litter size and vagina-cervix catheter penetration length in gilts. Reprod Dom Anim 36: 297-300

Rydhmer L, Eliasson-Selling L, Johansson K, Stern S, Andersson K 1994: A genetic study of estrus symptoms at puberty and their relationship to growth and leanness in gilts. J Anim Sci 72: 1964-1970

StatSoft, Inc. 2008: STATISTICA (data analysis software system), version 8.0

Szostak B 2010: The influence of the intensity of the growth of sows on the morphological features of their reproductive organs (in Polish). Rocz Nauk PTZ 6: 87-93

Tarocco C, Kirkwood R 2002: Vaginal length is not related to subsequent litter size of gilts. J Swine Health Prod 10: $124-125$

Tydlitát D, Vinkler A, Czanderlová L 2008: Influence of crude protein intake on the duration of delivery and litter size in sows. Acta Vet Brno 77: 25-30

Vallet JL 2000: Fetal erythropoiesis and other factors which influence uterine capacity in swine. J Appl Anim Res 17: 1-26

Wu MC, Dziuk PJ 1995: Relationship of length of uterus in prepubertal pigs and number of corpora lutea and fetuses at 30 days of gestation. Anim Reprod Sci 38: 327-336 